\title{
DIGITAL VILLAGE TRANSFORMATION: A MODEL FOR RELATIVIZ- ING REGIONAL DISPARITIES IN THE REPUBLIC OF SERBIA
}

\author{
Aleksandar Manasijević́1, Marko Milojković ${ }^{1}$, Dejan Mastilo \\ date of paper receipt: \\ date of sending to review: \\ date of review receipt: \\ 05.11.2019. \\ 07.11.2019. \\ 15.11.2019. \\ Review Article \\ doi: 10.2478/eoik-2019-0013 \\ UDK: 004.738.5:658.8(497.11) \\ ${ }^{1}$ Faculty of Economics, University of Niš, Serbia \\ ${ }^{2}$ Faculty of Business Economics, Bijeljina, Bosnia and Herzegovina
}

\begin{abstract}
The regional reality of the Republic of Serbia is characterized by strong regional disparities and adverse demographic trends. This situation is the result not only of inadequate actions of makers of macroeconomic policy and implementation of inefficient models of regional development in modern conditions, but of a long-term process of inheritance and deepening of regional disparities. The consequences of uneven regional development are numerous, and despite the economic ones, it is very important to emphasize the importance of non-economic consequences of uneven regional development. This primarily refers to the unfavorable demographic flows caused by the bipolarization of the state to the developed north and undeveloped south. Migratory trends in the Republic of Serbia can be observed in three different, however, interrelated processes. The first relates to migration from villages to cities, the second to migration from south to north and the third to migration directed beyond the borders of our country. These processes led to the extinction of the Serbian village and to the demographic emptying of the periphery of the Republic of Serbia. This is best supported by the fact that every fourth village is in the process of demographic disappearance, while every fourth agricultural resident of the Republic of Serbia is at risk of poverty. However, in the Zajecar district, the municipality of Sokobanja, one can notice the digital transformation of Vrmdža village, similar to the digital transformation of villages in developed countries. This transformation has attracted a large number of young families from this village doing business activities through the internet and modern digital technologies. The aim of this paper is to investigate the digital transformation of the village of Vrmdža by presenting a specific model of village transformation that can significantly contribute to the relativization of regional disparities in the Republic of Serbia.
\end{abstract}

\section{Keywords:}

Regional development, regional disparities, village transformation, digital technologies, new model of regional development.

JEL: R10, R11. 


\section{INTRODUCTION}

The contemporary economic reality in the Republic of Serbia, among other things, is characterized by pronounced regional differences at all levels. However, the problems of uneven regional development have a multiplied negative effect on almost all segments of society, both economic and non-economic. One of the most intense impacts is reflected in the negative impact of pronounced regional differences on demographic flows.

Given the polarization of the Republic of Serbia into the more developed north and the undeveloped south, "... the labor force by nature migrates to places with higher average incomes, that is, to those places where they will have better living conditions." (Manasijević, 2018, p. 5 ). This, on the one hand, leads to the emptying of some parts of our country, while, on the other hand, such demographic flows are a barrier to the implementation of regional policy measures and instruments, since these areas are left without their basic development resource - people.

In modern conditions, when it is obvious that most villages in the hilly and mountainous regions, most often South and Southeastern Serbia, become almost completely demographically empty, it is of utmost importance to create and implement regional policy measures and instruments in order to stop and then reverse this process. However, measures and instruments of regional policy cannot be applied spontaneously, but must be envisaged by the long-term strategy of regional development of the Republic of Serbia, which does not exist in modern conditions.

This situation in the Republic of Serbia is not a product of exclusively contemporary conditions, but has its roots in a relatively distant historical period. With that in mind, a chronological analysis of regional development in the Republic of Serbia, followed by an analysis of regional reality, needs to be done for a more accurate and relevant analysis. These analyzes need to be conducted in order to create a specific theoretical framework that is needed to create measures and instruments to overcome the aforementioned situation.

In addition to classical, or rather traditional methods, today, it is possible to use certain modern methods, with the help of digital technologies, to reduce regional differences. An example of this can be found in the Republic of Serbia. Namely, the village of Vrmdža, the municipality of Sokobanja implemented modern digital technologies and created a so-called rural hub from which modern freelance jobs can be performed. They called this approach "rurban" which, as the name implies, is a combination of rural and urban development. Such a decision proved to be extremely good, because a large number of young married couples, mostly millennials, decided to settle in the territory of this village and from there they did their jobs.

In this sense, after analyzing the situation in the territory of Vrmdža village, the aim of this paper is to create an approach that can be applied in other villages in the Republic of Serbia, which can have far-reaching positive effects on regional development and demographic trends in our country.

\section{CHRONOLOGICAL ANALYSIS OF REGIONAL DEVELOPMENT OF THE REPUBLIC OF SERBIA}

Before starting the chronological analysis, it is necessary to briefly define the phenomenon of regional development. If we start from the general theory of the system, society can be seen as one big system, but also the economy, which is one of the most complex subsystems of society, can be seen as a large economic system. (Cobeljic, 1974). In this sense, and given the complexity of the economy as a system, the process of economic development can be characterized as one of the most complex processes.

However, the process of economic development is not a process which, colloquially speaking, is floating, but is taking place in a certain space. In this sense, regional development in the broad sense can be defined as observing the process of economic development through the so-called regional prism. In the narrow sense, regional development can be defined as a process in which a large 
number of actors, at different hierarchical levels, in a given territory (national economy, region, district, even local government), influenced by a large number of internal, external, subjective and objective factors achieving optimally balanced economic development. (Manasijevic, 2018). It should be borne in mind that evenly balanced development cannot be achieved in practice, and even if possible it would adversely affect economic development. (Aranđelović and Gligorijević, 2010).

Considering the above, while certain regional differences can be stimulating to achieve the goals of economic development, it must be taken into account that they move within the socially acceptable boundary, because if regional differences become socially unacceptable, then this constitutes a problem that impedes the course of the economic life of a country. However, in the literature, however, there is no exact and unique definition that defines this boundary.

In line with changes in the global environment, social, political, and on that basis, economic systems, the role, way of observing and understanding of regional development in economic theory is changing. Today, almost fifty years since the so-called "golden age" of regional development, the problems of uneven regional development are more acute than ever in almost all countries of the world, regardless of their level of development.

In addition, the problem of uneven regional development, not only exists as such but, on the contrary, has its multiplied negative effect in all pores of socio-economic reality, precisely in proportion to the increase in regional disparities. In order to apply regional policy measures and instruments in the right way today, producing positive results, it is necessary to view the phenomenon of regional development from a long-term, strategic perspective.

However, when designing an adequate, long-term, regional development strategy, it is necessary to first consider the historical course of the theory and policy of regional development of the Republic of Serbia.

Throughout history, the Republic of Serbia has repeatedly changed its borders, state systems and rulers, was occupied, territorially classified into several empires, divided into sandzaks, sections, districts, baninas and regions. The roots of many of the problems of regional development that the Republic of Serbia is facing today lie in a relatively long period of time.

In that sense, a chronological analysis of the phenomenon of regional development should be carried out in order to provide a more detailed analysis needed to create a strategic basis for regional development of the industry of the Republic of Serbia. With this in mind, the aim of this part of the paper is to review the historical course of the theory and policy of regional development of the Republic of Serbia.

\subsection{REGIONAL DEVELOPMENT OF SERBIA UNTIL THE FIRST WORLD WAR}

Regionalization in Serbia was, to a certain extent, represented in the Sretensky Constitution of 1835, with the envisaged districts, districts and municipalities. (Aranđelović, Gligorijević, 2010)

During this period, the districts, for the first time, receive a certain amount of autonomy in the decision-making process crucial for the smooth life of the people who exist in particular regions. The acquisition of a certain, limited, autonomy, as well as the gradual disconnection with the former, feudal, system opens the space for the development of certain regions in the Principality of Serbia of that time.

In the period of the Kingdom of Serbia, after the previous enlargement of the territory, the introduction of dinars and the establishment of the Privileged National Bank, the conditions for the rapid development of the capitalist economy were created. Since domestic accumulation was insufficient, with the great help of foreign loans, mines and industrial enterprises were opened, roads and railways were built, as well as other infrastructure networks and more. However, despite the initiated, accelerated, industrial development, the Kingdom of Serbia was, in this period, a predominantly agricultural, underdeveloped, European country. 
Viewed from the aspect of regional development, the initiation of the process of industrialization, on the one hand, resulted in the development of certain regions, while on the other, it created regional disparities in relation to other, predominantly agricultural oriented regions. After all, this situation was also largely characteristic of the economy of the Kingdom of Serbs Croats and Slovenes, later the Kingdom of Yugoslavia.

However, regional disparities that emerged in the initial period of development of the economy of the Kingdom of Serbia have become more pronounced over time as a result of the absence of adequate regional policy. The development of the economy of the Kingdom of Serbia interrupted the appearance of the First World War (1914-1918), until then the most devastating war in human history.

\subsection{REGIONAL DEVELOPMENT OF SERBIA BETWEEN THE TWO WORLD WARS}

After the First World War, the Kingdom of Serbia, as well as other European countries, faced a demographic disaster, devastated economic and transport infrastructure, as well as part of the territories that needed to be included in certain countries. Then, as a realization of the longstanding aspirations of the descendants of the Southern Slavs, a new, great state was formed - the Kingdom of Yugoslavia.

From an economic point of view, the Kingdom of Yugoslavia was a highly heterogeneous country. Namely, on the one hand, one can notice a relatively developed capitalist economic system in Croatia, Slovenia and Vojvodina, while on the other hand, in other republics economic life takes place in an almost natural form of economy. (Manasijevic, 2018)

If we analyze the economic development of the Kingdom of Yugoslavia, we come to the following conclusions:

(1) According to European criteria, the Kingdom of Yugoslavia was one of the underdeveloped, predominantly rural, even agrarian overpopulated countries, with a low level of industrial production development;

(2) the structural and economic-systemic imbalances between the countries that made up the Kingdom have made it very difficult to achieve long-term, sustainable, economic development and

(3) uneven spatial distribution of investments, high presence of foreign capital, most often in more developed regions, but also lack of interest and inadequate, delayed, economic policymakers' actions lead to an increase in regional disparities which, even then, triggered population migration and capital migration from underdeveloped regions and underdeveloped regions into more developed regions of the Kingdom of Yugoslavia.

Thus, in the early 1940s, the Kingdom of Yugoslavia was still in the process of overcoming both the effects of the First World War and the internal, economic and non-economic problems that had arisen in the previous period. However, this process, as well as the process of further economic development of the Kingdom of Yugoslavia, is interrupted by an even more devastating World War II.

During the Second World War, the Kingdom of Yugoslavia experienced a new demographic disaster without recovering from the previous one. Economic facilities and transport infrastructure are again destroyed, state wealth dislocated from the country, and the Kingdom of Yugoslavia territorially divided. This situation, after the end of the Second World War, represented a great barrier to achieving the goals of economic development.

\subsection{REGIONAL DEVELOPMENT OF SERBIA AFTER THE SECOND WORLD WAR}

After the end of World War II, Yugoslavia was faced with an undefined system of government, demographic catastrophe and other consequences of the war. German and other military, occupying, forces withdrew large amounts of state wealth during the withdrawal, destroying much of the remaining economic and transport infrastructure. 
This situation brought the former Yugoslavia to the brink of socio-economic, as well as demographic, political and, ultimately, social failure, which required immediate implementation of the radical, corrective measures and instruments needed for the country's recovery.

It is just such radical changes that have been implemented. Namely, in the elections held after the war, the former state system was replaced by a new, socialist one, which meant changes in almost all fields of the socio-economic system.

Accordingly, the Kingdom of Yugoslavia changes its name and borders, and then a new state emerges - the Socialist Federal Republic of Yugoslavia. In economic terms, the postulates of socialist or, rather, Marxist economic theory were applied in the economy of the new state.

The high level of devastation of the country, the pronounced regional mismatches and the low standard of living required the immediate reaction of the state as the only actor that could have overcome this situation. This, in the beginning, meant a very centralist approach (similar to the Soviet Union) in the development of economic life.

All decisions regarding the organization and functioning of the economic system were made from one center while it was up to the business entities to execute the plans of the central commission. Large regional differences, inherited from the previous period, have emerged as the central problem of the economy of the SFRY, so they have to be overcome as soon as possible.

This is not only because the pronounced regional differences adversely affected all segments of socio-economic reality, but also due to the fact that the regional, as well as any other, distinct differences were contrary to the socio-political dogmas on which the foundations rested Socialist Federal Republic of Yugoslavia.

However, the problem of uneven regional development of the Socialist Federal Republic of Yugoslavia was a very complex problem, whose roots were in a relatively long historical period. However, it should be borne in mind that the overall level of economic development and standard of living of the whole country was very low.

In this sense, the economic policy-makers of the Socialist Federal Republic of Yugoslavia were forced to apply only regional policy during that period. The policy concerned the simultaneous, parallel development of all regions and accelerated economic development of the whole country. In doing so, regions that were less developed had to develop significantly faster to reach more developed regions.

Such regional policy was only possible in such a socialist state system, where each development process was planned in a detailed and centralized way, for all republics, at the state level. Regarding regional development methods, the same method was adopted for all (both developed and underdeveloped) regions, which was industrialization. (Aranđelović and Gligorijević, 2010)

If we analyze and observe in more detail the overall regional development policy of the Socialist Federal Republic of Yugoslavia, we conclude that its essence is precisely in the principle of uniformity, while its basic tool, that is, the method of industrialization.

Namely, the conception of regional development policy, on the principle of equality, was the only and possible solution, given the essence of mitigating regional differences and also the conditions that existed in the SFRY at the beginning of its development. (Rosic and Gligorijevic, 2001)

Why industrialization? First of all, it is important to mention that the regionalization of the Socialist Federal Republic of Yugoslavia was carried out according to the political-territorial principle, that is, viewed from the state level, into six republics and two autonomous provinces. Thus, the regionalization of the SFRY was not conducted on the basis of purely economic but also political and national-ethnic principles.

Developmental mismatches between republics and autonomous provinces were very pronounced. However, the views of the policy makers of the SFRY were that, although it is to be balanced, it must not be done on the principle of general leveling between developed and underdeveloped republics. In this sense, the industrialization of the SFRY has become the most acceptable method of regional policy. 
This is because, on the one hand, industrialization allows economically more developed republics to continue their development, while, on the other hand, less developed republics in the so-called "revolutionary leaps" can reach them. In doing so, it has to be noted that agricultural degradation in relation to industry during this period is remarkable, which will later show its negative effects. The application of industrialization methods results in accelerated economic and generally social development, and regional differences, both between individual regions and between republics and autonomous provinces, are mitigated. This peroid is characterized by very high rates of economic growth, renovation and modernization of old and construction of new industrial plants, renovation and construction of transport infrastructure, growth of exports, as well as positive movement of all economic parameters. Economic development was then planned and implemented through the so-called five-year social development plans, in which the concept of regional development equilibrium had a central place.

The 1971 Constitutional Amendments and the new 1974 Constitution, republics and autonomous provinces give greater autonomy in different fields, one of which is to define and achieve the goals of economic development within its borders. Such a decision was presented as the integration of the SFRY into the framework of the global trends of the time, and the organization of the state in the same way as the countries of the West.

However, very quickly, it turned out that such constitutional changes had negative consequences on the socio-political as well as on the economic, or economic, system of the Socialist Federal Republic of Yugoslavia.

Namely, from the economic point of view, the unevenness of economic development is becoming more pronounced, and therefore, regional differences at all levels are increasing. The more developed republics, Slovenia and Croatia, are less and less sharing their accumulation without paying attention to the less developed republics and provinces.

At the beginning of the last decade of the 20th century, all the socio-economic and political circumstances in the SFRY signaled the unsustainability of Yugoslavia's survival and its ultimate disintegration. During this period, regional disparities between the regions and between the Yugoslav republics were on a constant and extremely rapid increase.

The final breakup of the Socialist Federal Republic of Yugoslavia began with the separation of Slovenia from Yugoslavia on 25 June. 1991. In the period 1991-1995, a civil war was taking place in the area, now formerly SFRY, during which the destruction of economic and transport infrastructure and a new demographic catastrophe occurred again.

\subsection{REGIONAL DEVELOPMENT OF SERBIA AFTER THE BREAKUP OF THE SFRY}

After the breakup of the Socialist Federal Republic of Yugoslavia, the two remaining socialist republics (Serbia and Montenegro) formed a state union called the Federal Republic of Yugoslavia. Since its inception, the FRY has been confronted with numerous socio-political problems and pressures such as war conflicts in Bosnia and Herzegovina and Croatia, sanctions imposed by the international community, NATO aggression in 1999 and so on. With this in mind, decision-makers at the state level could not fully address the economic problems and thus the problems of regional development.

Seen from a regional development perspective, many issues in the FRY needed to be rethought. One of those was the division of the country into macroeconomic regions. Guided by specific socio-economic criteria, makers of FRY macroeconomic policies divide into four macroeconomic regions: Central Serbia, Vojvodina, Montenegro and Kosovo and Metohija.

Also, it should be borne in mind that the Federal Republic of Yugoslavia was facing an impaired economic structure, which needed to be reorganized urgently to meet the needs of the new state. Regional differences in this period were very pronounced, however, with the inadequate actions of economic policy makers of the period, they were not mitigated. 
After 2000, the relative reintegration of the FRY into international flows occurs, which, on the one hand, allows for accelerated economic development, while on the other hand, it begins intensively with the process of structural transformation, privatization and, ultimately, violent deindustrialization. which, in the future, proved to be disastrous for the economy of the Republic of Serbia.

On February 4, 2003, the Federal Republic of Yugoslavia changed its name to Serbia and Montenegro. These changes were not only about the name of the state, but with the change of the entire political system, the basis for complete independence of the two countries was created, which happened by the separation of Montenegro in a referendum on May 21, 2006.

By separating Montenegro from Serbia, the independent Republic of Serbia is restored, to the extent that it is still current. The Republic of Serbia is again confronted with a broken economic structure, as well as with destabilization in Kosovo and Metohija, culminating in the unilateral declaration of Kosovo's independence on February 17, 2008. Since then, although it has not recognized Kosovo's independence, the Republic of Serbia does not have complete control over the socio-political and therefore economic life in the territory of the Kosovo and Metohija regions.

All these problems have further intensified the already existing economic problems, and thus the problems of uneven regional development, which are current and in the present conditions.

\section{REGIONAL DEVELOPMENT OF THE REPUBLIC OF SERBIA IN MODERN CONDITIONS}

Today, almost twentyyears after the start of the process of structural transformation and privatization, none of these processes has been completed, the structure of the economy of the Republic of Serbia is distorted and almost completely left to spontaneous formation, while the problems of regional development and demographic flows are greater than ever.

It can be noted that the Republic of Serbia has not recorded a sufficiently long period of stability, strategic planning and management of regional development, necessary to overcome the decadesold regional differences. On the contrary, the formulation and implementation of economic policy in the Republic of Serbia depends to a large extent on political processes, and thus, with every change of government, there is a change in the economic and thus regional policy of our country. All of the above contributed to the current situation in the economy of the Republic of Serbia, characterized by one of the most pronounced regional differences in Europe, extremely unfavorable demographic flows, devastated domestic economy and so on.

The Republic of Serbia has an area of $88499 \mathrm{~km} 2$, it is divided into five statistical regions, the largest of which is Sumadija and Western Serbia with an area of $26493 \mathrm{~km} 2$, and the smallest Belgrade region with an area of $3234 \mathrm{~km} 2$.

However, although territorially the smallest, the Belgrade Region has the highest investment rate and a constant inflow of population, making it the most developed region in the administrative, political and economic center, while, paradoxically, with the decrease in the level of development of the region, investments in the region are also declining.

The population of the Republic of Serbia after the First World War has been steadily increasing, while all population structures have been developing, however, in recent years there have been tectonic changes in the number and structure of the population, whose analysis has led to worrying data.

The Republic of Serbia has a population of 6,982,604 (-5.5\% compared to last year). 1 Comparing this with the 2002 population of 7,498,001, we can conclude that the Republic of Serbia has lost about 515,397 inhabitants in seventeen years.

Numerous factors have contributed to the dramatic decline in population, but the two most influential factors are:

1 Estimation of the Statistical Office of the Republic of Serbia for 2018 
(1). negative natural increase $(-37,700) 2$ i

(2). the phenomenon of emigration of a large population, most commonly the highly educated known as the "brain drain".

In the contemporary conditions in the Republic of Serbia, the phenomenon of migratory movements in the south - north direction, accompanied by the apparent emptying of the southern and southeastern parts of our country, is one of the basic developmental and existential problems, the consequences of which most citizens of the Republic of Serbia suffer, whose multiplication will be negative. effect to suffer future generations.

Negative migratory movements in the Republic of Serbia can be broken through two separate, but at the same time driven processes. The first, as mentioned above, refers to intra-country migration in the south-north relation, while the second refers to externally oriented migratory movements, most often to developed countries.

Unfavorable demographic trends do not represent the cause but the consequence resulting from the pronounced regional differences in the Republic of Serbia. The regional differences in our country are one of the biggest in Europe. The ratio between the most developed and underdeveloped administrative district is $7: 1$, and the ratio between the most developed and underdeveloped municipality is even 15: 1. (Regional Development Strategy of the Republic of Serbia for the period 2007-2012).

The Belgrade region, as the most developed one, participates in the creation of national gross domestic product with $40.4 \%$, while the region of South and Southeast Serbia participates with $13.8 \% 3$. Analyzing the participation of the regions in the creation of national GDP in the period from 2009 to 2019, it can be noticed that the Belgrade region has an increasing participation rate, while other regions in the Republic of Serbia are falling.

These data just confirm the paradoxical thesis that the most developed regions in the Republic of Serbia are becoming more developed, while the underdeveloped are left to the spontaneous operation of the market and become even more underdeveloped.

In the future, such trends could seriously endanger the survival of the people in the interior of our country, and their gradual emigration and the territorial integrity of the Republic of Serbia.

However, if we look at the structure of the economy, we can notice numerous mismatches and regional-economic anomalies resulting from, almost completely, the absence of a strategic aspect in planning economic and, consequently, regional development.

Analyzing personal consumption data by region, we see that food and housing expenditure is dominant in all regions. However, we can observe that expenditure on health, education, recreation and culture and clothing and footwear are declining in proportion to the development of the region. On the other hand, we can see a markedly higher percentage of income allocated to alcoholic beverages and tobacco in underdeveloped regions.

It should be borne in mind that in the first quarter of 2019 the average monthly income per household amounted to RSD 65,872, while the expenditures for personal consumption amounted to RSD 66,064. 4

The status of regional development in the Republic of Serbia is as follows. Out of 174 local selfgovernment units, 41 municipalities have a level of development of $60 \%$ to $80 \%$ of the national average, while 46 municipalities belong to devastated areas with a level of development below $50 \%$ of the national average. Most undeveloped municipalities are located in the regions of southern and southeastern Serbia. (Manasijevic, 2018)

According to the Statistical Office of the Republic of Serbia, such trends are present in other areas, so if we look at the number of households that own a computer, we will again notice significant differences between the Belgrade region, where $80 \%$ of families own a computer, while, for example,

$2 \quad$ Statistical Office of the Republic of Serbia - Statistical Yearbook 2018.

3 Statistical Office of the Republic of Serbia - Regional Gross Domestic Product from 2009 to 2019.

4 Statistical Office of the Republic of Serbia - Household Income and Consumption in the Republic of Serbia, second quarter of 2019. 
this percentage in the region of South and Southeast Serbia 63.3\%.5

Similarly, if we look at the value of construction works in the Republic of Serbia by region, we can see that the Belgrade region and Vojvodina account for $79.8 \%$, while the region of South and Southeast Serbia accounts for only 17.3\%. On the other hand, the number of persons connected to the water supply system is the smallest in the region of South and Southeastern Serbia - 48.3\%, while in the Vojvodina region this percentage is $97.3 \% .6$

If we look at the totals of most of these indicators for the entire territory of the Republic of Serbia, we can see that they are constantly increasing. However, when we look at the values of the same indicators from the perspective of statistical regions, we can conclude that regional differences are also constantly increasing.

These data represent a very relevant indicator of the development of certain regions, but also of the standard of living of the people who exist in those regions. Although this data is getting worse from year to year and regional differences are increasing, there is no indication that the aforementioned trend will stop and change for the better in the coming period.

When it comes to the causes that have led to an increase in regional disparities, it is clear that the primary place must be given to the volume and structure of investments. "Insufficient investments and their unilateral structure could not have led to changes in the economic structure of the production of underdeveloped regions" (Rosić, 1977).

If we look at investments in fixed assets by regions in the Republic of Serbia, we will come to a paradoxical conclusion. The more developed regions in the Republic of Serbia have the highest rate of investment, while with the decline in the development of the regions, the investments in the same decrease. However, dominant investments in fixed assets can be observed in the Belgrade region.

Conducting such a regional development policy will lead to an increase in regional disparities in the Republic of Serbia, which will further deepen demographic, social and other social problems, all of which will result in the complete demographic and economic emptying of these territories in the future.

\section{THE IMPORTANCE OF THE VILLAGES FOR THE REGIONAL DEVELOPMENT OF THE REPUBLIC OF SERBIA}

The importance of a village in the economic life of a country is indisputable. During the historical development of a country, the basis for industrialization was almost always made up of a strong agriculture sector (food production needed for the workforce) and a strong village.

Currently, the position of villages in the Republic of Serbia is in jeopardy. However, despite the importance that agricultural production definitely has for the entire economy, there has been a trend of rural depopulation in the Republic of Serbia for many years. Every fourth village in the Republic of Serbia is in the process of disappearing demographic population and has fewer than 100 inhabitants. (Manasijevic, 2018, p. 5). If we look at the villages by regions in the Republic of Serbia, we can conclude that the most endangered ones are located mainly in the mountainous areas in the south and southeast of our country.

The analysis of the situation shows that if this trend continues, in the next ten years, most of these villages will be completely empty. Considering the high unemployment rate in the overall labor market, as well as our villages abound in natural resources that represent a comparative advantage of the Republic of Serbia, we are in a paradoxical situation.

Exports of goods and services have been retaining the upward trend for years, which stood at $10.8 \%$ for the period from January to August 2019, based on the growth of exports of services, products of the manufacturing industry and agriculture. Rural landscapes provide the basis for all

$5 \quad$ Statistical Office of the Republic of Serbia - Regions in the Republic of Serbia in 2018.

6 Statistical Office of the Republic of Serbia - Regions in the Republic of Serbia in 2018. 
three segments of this growth trend. Services in the field of agriculture can be based on the entire range of rural areas, primarily rural tourism, hospitality and other services offered by agricultural producers. A key segment for export is the tourism supply of these areas.

Manufacturing is based on the processing of produced and exploited raw materials. Most of these raw materials are produced on agricultural holdings and in agricultural enterprises, which are the dominant form of organizing production activities in rural areas.

The importance of agriculture's participation in the balance of payments is evidenced by the fact that the value of agricultural exports in 2018 amounted to $\$ 3,364.2$ million and that the surplus in the trade balance of payments amounted to $\$ 1,338.1$ million. Considering that most of the exports are raw products whose value could be multiplied by processing, investments in this industry are imperative.

Considering the fact that we live in a time when knowledge is a key resource, education and respect for best practice countries is key to further progress and achieve prosperity in agriculture, especially organic. However, there are many problems that are slowing down and hampering agricultural reform.

One of the additional problems that hinders the development of agriculture is the fragmentation of farm holdings. Smallholder farmers are generally incapable of expanding estates and often of cultivating existing ones, which creates a risk of poverty for that part of the rural population. In order to provide modern machinery, lease or purchase agricultural land and cultivate land, largescale basic capital is required, which, generally, cannot be provided by individual producers. Without subsidizing, unifying and favorable lending to farmers, as well as favorable macroeconomic conditions, their survival is uncertain.

The village as a predominant food producer has a direct impact on the quality of life and nutrition of the population. Therefore, it is imperative to influence the development of organic production and to create a sustainable concept of village development. The area particularly suitable for the development of organic production is represented by mountainous regions.

Mountainous regions cover about $20 \%$ of our country's territory, $40 \%$ of which is suitable for arable land. Agricultural production is generally extensive with low application of mechanization and artificial fertilizers, chemical means of protection and without the influence of intensive (conventional) agriculture. The plots are generally small and have a variety of rows. (Kovacevic, Oljača, 2005). The land in these parts is generally of inferior quality and has a large share of arable land, which represents an excellent, accessible potential for organic production and agriculture.

As $30 \%$ of the working age population lives in these parts, producers will have no problem with labor shortages. Therefore, we conclude that there is exceptional potential for organic production, that there is a surplus of vacant land and the necessary manpower. Rural tourism is of particular importance as the second segment. Rural tourism is a form of tourism where tourists reside in rural areas and where they are offered other services besides accommodation and food. Service providers are most often represented by agricultural producers who, in addition to their primary occupation, provide tourist services as a secondary activity.

By making better use of excess housing and allowing access to rural amenities, producers can reap additional economic benefits. Through the realization of these positive effects, the well-being of the rural population is directly increased and unemployment is reduced. This can also have a positive effect on the negative migratory movements from village to town due to adverse economic conditions and lack of jobs.

The sale of agri-food products and the provision of tourism services on their own property is generally a significant motive for owners of farms to engage in this activity. By shortening the buysell process, by meeting the buyer and seller without a middleman and by realizing the product or service at the point of sale, consumers are sold fresh products and customized service with significantly lower transaction costs. Often farms engaged in providing tourist services cannot provide all the necessary resources for an adequate offer to tourists, which gives other farmers from 
the surrounding area a chance to market their products.

Rural tourism also solves the problem of employment, especially of the female working age population in the countryside, which has fewer job opportunities in labor intensive physical jobs. The female population is usually in demand for the jobs of receiving, housing and catering for tourists.

The development of rural tourism has the effect of revitalizing estates and strengthening the material basis of rural households, increasing the standard of living and influencing the development of the entire rural community. Tourism, as a secondary activity in rural areas, gives farmers the opportunity to earn more. This improves living conditions, raises the level of culture and education in underdeveloped areas. All these have positive implications for reducing the economic and social disparities between rural and urban communities.

Based on all the above, it can be concluded that the role of villages in the process of achieving the goals of more balanced regional development is extremely important. However, if the aforementioned trend of demographic discharging of villages continues, it will be too late to implement regional policy measures and instruments - the villages will be completely empty. Namely, these trends introduce the economy of the Republic of Serbia into a kind of vicious circle, where as a consequence of uneven regional development unfavorable demographic flows occur, which later represent a barrier to the implementation of measures and instruments of regional policy. However, it should be borne in mind that if villages in the periphery of the Republic of Serbia become demographically empty, this opens up space for the settlement of people from the surrounding countries, which can ultimately endanger the territorial integrity of our country.

However, in modern conditions, with the use of new, digital technologies, the space for revitalization of a number of villages in the Republic of Serbia opens. Namely, the current trend in the countries of the West is the exact opposite of our country. Given the increasing number of jobs that can be done through digital technology, many jobs are no longer strictly site-specific. This allows people from mostly polluted cities to move their business activities to villages where they naturally need working conditions (digital technologies). This is exactly where the so-called rustic approach that was implemented in the Republic of Serbia in the village of Vrmdža comes to the fore.

\section{VRMDZA RURBAN ACCESS MODEL FOR VILLAGE REVITALIZATION}

Vrmdža is located in the Republic of Serbia in the Zajecar Administrative District, on the territory of Sokobanja Municipality. According to the latest census (2011), this place has 497 inhabitants. Considering the positive tendencies present in this village, it was taken as a representative example to conduct research and identify the implications of positive trends.

The village itself has a lot of tourist potential. As one of the oldest settlements in this region, Vrmdža is full of historical sites. It is first mentioned in written documents in the 3rd century n. e. In the center of the village is Latin - a town, a Roman fort whose purpose, during that period, was to defend the imperial road that bound the Middle and Middle East. In the 6th century, the city was rebuilt to protect Byzantium from invasion by Slovenian tribes. Later the city was mentioned in the 14 th century as a fortified habitat for wealthy landlords who, at that time, traded with merchants from Dubrovnik.

Although there is a trend of depopulation in this place, with more than 1,500 inhabitants living in the post-World War II period, there have been positive trends over the last ten years that have slowed this trend and are threatening to change its course in the future. This is supported by the fact that in the last ten years over 35 houses and plots have been purchased in this place. According to the 2011 census report, the village of Vrmdža had 497 inhabitants. Today, it is estimated that the village lives

Vrmdža is located in the Republic of Serbia in the Zajecak Administrative District, on the territory of Sokobanja Municipality. According to the latest census (2011), this place has 497 inhabitants. 
Considering the positive tendencies present in this village, it was taken as a representative example to conduct research and identify the implications of positive trends.

Although there is a trend of depopulation in this place, with more than 1,500 inhabitants living in the post-World War II period, there have been positive trends over the last ten years that have slowed this trend and are threatening to change its course in the future. This is supported by the fact that in the last ten years over 35 houses and plots have been purchased in this place. According to the 2011 census report, the village of Vrmdža had 497 inhabitants. Today, it is estimated that the village lives about 580 inhabitants.

\section{Figure 1: Population settlementGrafikon1: Vrmdža}

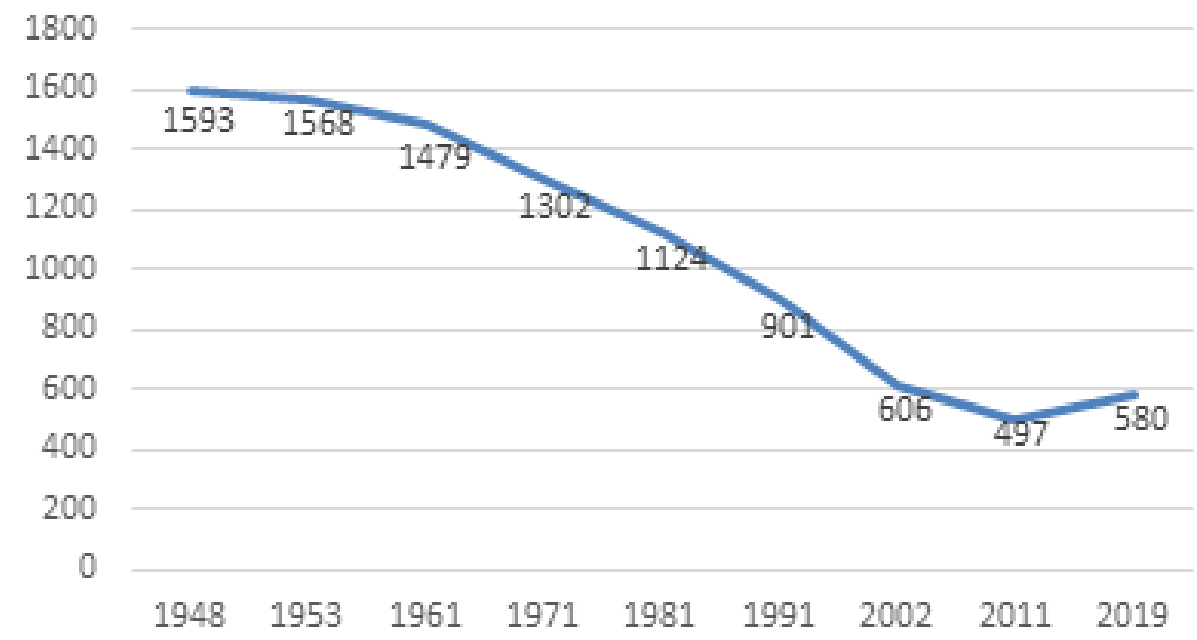

Source: Statistical Office of the Republic of Serbia - Statistical Yearbook and Author's calcutation Based on Field Surveys.

Opportunities to engage in a variety of activities and the support provided by the Rural Hub attract new residents to this place. The new residents are mostly young couples who come from cities in Serbia, but also from countries abroad. Considering the age structure of the people who move to Vrmdža village, it is expected that the process of demographic growth will continue in the coming period.

The settlement of the new population is influenced by the existence of numerous natural beauties, agricultural and tourist potentials, as well as the establishment of the Rural CUB. The Rural Hub is a hub for social local entrepreneurship with the idea to develop a socially responsible idea and has been in existence since 2010.

The Hub's business alone is based on three pillars of work: (1) Rural development and village revival, (2) Eco village, and (3) Domestic handicraft.

Rural Hub works to encourage and support the local community by using its products and services to preserve nature, traditions and family farms. The Hub is a coworking space accessible to individuals and organizations for learning, project implementation, teaming, and meeting. In addition, the Rural Hub is also concerned with the development of the local community through the development of products and services and the networking of locals, all with the aim of encouraging small family businesses and preventing migration from the countryside, especially when it comes to the young population.

The Center for Socially Responsible Entrepreneurship - CDOP was established as an organization that will bring positive effects to rural development. The vision of this center is to be an incubator for creating and developing socially responsible ideas that enhance the quality of life. In cooperation with the CDOP and the Vrmdža local community, a manual called "Eco Village - Model for Village Revitalization" was created, covering organic food production, eco-construction, energy supply systems, good economy with social entrepreneurship, eco-tourism, women's entrepreneurship and other.

One of the prominent projects that the Hub has implemented is the creation of an interactive map "Through Vrmdzha and Centuries", which is a digital assistant to visit and get acquainted with this 
village, its sights and history. The project was realized with the cooperation of locals, students and experts. The interactive map is also available as a mobile app and can be found on the Google Play Store. It is also available for offline use. As such, it makes access to the village easier and plays the role of a kind of digital travel guide.

Vrmdža village is famous for eco tourism. It is close to numerous tourist destinations. The village itself has a view of the Rtanj mountain at the base of which. Also nearby is Vrmdzhan Lake, Sokobanja is $15 \mathrm{~km}$ from the village, Bovan Lake is $22 \mathrm{~km}$ away. This provides tourists with content that can complement a multi-day tourist stay in the village.

Within the parish home of the village is a permanent exhibition of the museum, which displays old folk costumes, tools, utensils made of wood and pottery and a number of old objects of this area. The remains of the old church of Sv. Three, and there are several old buildings dating from the late eighteenth and early nineteenth centuries.

The accommodation offer is highlighted on the website www.soko-banja-smestaj.com, which includes the accommodation of the entire municipality. The site offers offers in 7 different languages, which neutralizes language barriers to inform and plan your stay in the area.

During the year, there are more cultural and tourist events in Vrmdza that bring together a large number of tourists. And in more detail, interested visitors can access the website on the village's website www.vrmdza.org.rs.

In the village itself, the so-called "Rurban" approach is promoted and implemented, which represents the fusion of new technology with the traditional one. With this approach, locals and newcomers in their lifestyles and businesses strike a balance between technology and tradition. By combining urban and rural heritage and knowledge, traditional and contemporary knowledge and technology, younger and older generations, those from the countryside and those from the cities, positive results are achieved in promoting rural tuzism, empowering the rural population for employment and more.

\section{CONCLUSION}

Problems of uneven regional development and demographic trends present in the Republic of Serbia for decades. Their study has been addressed by a large number of researchers, organizations, and institutions. However, over time, problems of regional development and adverse demographic trends are becoming more pressing, which opens the door for new research. Bearing in mind the data analyzed above, we can conclude that in order to achieve the goals of more balanced regional development of the Republic of Serbia, it is necessary to create a long-term regional development strategy, limited in time, with clearly defined goals, measures and instruments of regional policy necessary to achieve them.

In order for the long-term goals of regional development to be achieved, it is necessary for the situation in the economy of the Republic of Serbia to be stable, with the continued achievement of a relatively high rate of economic growth. The basic goals of regional development of the Republic of Serbia are: accelerated economic development of all areas, with an emphasis on underdeveloped regions, long-term sustainable development, increase of regional competitiveness, reduction of regional inequalities and poverty, halting of unfavorable demographic flows and continuation of the process of decentralization.

The achieved level of development in the Republic of Serbia, as well as contemporary turbulent conditions, require detailed analysis and then radical planned changes in the vertical (branch) and horizontal (regional) economic structure. It is necessary to start the analysis of the situation in the economy of the Republic of Serbia from individual municipalities, through districts, regions, to the economy of our country as a whole. Based on the potential of certain municipalities, districts and regions, it is necessary to determine the activity and branch structure that will best exist in a particular area (region), and stimulate it in a planned manner. It is during this analysis that 
the potentials of villages in which it is possible to apply a model of digital village transformation modeled on the village of Vrmdža need to be specifically analyzed. Thus, with the use of modern digital technologies, the village of Vrmdža managed to stop the depopulation process and then reverse negative demographic flows (beginning of new population migration) in the conditions when most villages of the similar type in the Republic of Serbia disappear. The purpose of this descriptive analysis is to point out measures and instruments that can be applied in other villages in the Republic of Serbia, for the same purpose.

After the analysis, it is necessary to strategically formulate the measures and instruments of regional policy that are needed for the adequate implementation of the process of digital transformation of villages in the Republic of Serbia. However, the process of digital transformation of villages cannot be implemented without the strong role of the state, both in the formulation of measures and instruments and in the process of implementation. Although in modern conditions of a market economy guided by neo-liberal doctrine, the influence of the state on economic life is minimized, in our conditions timely, targeted and adequate state intervention is necessary to achieve the goals of long-term regional development of the Republic of Serbia.

The role of the state is especially important in the process of long-term planning of economic development. Long-term planning of economic and, therefore, regional development in modern conditions is imperative. Bearing this in mind, we can conclude that in the shortest period the creation of a long-term strategy of economic and regional development must be started, which will take into account the potentials available to the economy of the Republic of Serbia, and then define ways for their optimal utilization.

\section{REFERENCES}

[1]Manasijević, A. (2018): Demografski tokovi u Republici Srbiji kao posledica regionalnih dispariteta. Zbornik studentskih radova i projekata 1, strana 5-10., Niš: Ekonomski fakultet.

[2] Čobeljić, N. (1974): Privreda Jugoslavije, knjiga druga, Beograd: Savremena administracija.

[3]Manasijević, A. (2018): Perspektive regionalnog razvoja republike Srbije. Izazovi i perspektive savremene ekonomije i menadžmenta, Kragujevac: Ekonomski fakultet.

[4]Aranđelović, Z., Gligorijević, Ž., (2010): Regionalna ekonomija, Niš: SVEN.

[5] Rosić, I., Gligorijević, Ž., (2001): Regionalni razvoj Jugoslavije, Niš: Ekonomski fakultet.

Strategija regionalnog razvoja Republike Srbije za period od 2007. do 2012. godine, Beograd: Republički zavod za razvoj.

[6] Procena broja stanovnika za 2019. godinu. Beograd: Republički zavod za statistiku Srbije.

[7]Statistički godišnjak 2018. godine. Beograd: Republički zavod za statistiku Srbije.

[8]Regionalni bruto domaći proizvod od 2009. do 2019. godine. Beograd: Republički zavod za statistiku Srbije.

[9]Prihodi i potrošnja domaćinstava u Republici Srbiji drugi kvartal 2019. godine. Beograd: Republički zavod za statistiku Srbije.

[10]Regioni u Republici Srbiji 2018. godine. Beograd: Republički zavod za statistiku Srbije.

[11]Regioni u Republici Srbiji 2017. godine. Beograd: Republički zavod za statistiku Srbije.

[12]Rosić, I. (1979): Regionalna ekonomika Jugoslavije. Beograd: Naučna Knjiga.

[13]Kovačević D., Oljača S. (2005): Organska poljoprivredna proizvodnja, strana 261-301, Zemun:

Poljoprivredni fakultet.

[14]Gligorijević, Ž. (2018): Ogledi o regionalnom razvoju.Niš: Ekonomski fakultet.

[15]Milojković, M. (2019): Inovacije u poljoprivredi i regionalni razvoj Republike Srbije. Regionalni razvoj i demografski tokovi zbornik studentskih radova. Niš: Ekonomski fakultet.

[16]http://cdop.rs/

[17]https://ruralhub.rs/

[18]https://www.nbs.rs/internet/latinica/18/18_3/prezentacija_invest.pdf 